\title{
Bacteriological Profile and Antibiotic Susceptibility Pattern of Isolates from Ascitic Fluid among Patients Diagnosed With Chronic Liver Disease in a Tertiary Care Hospital: An Observational Study
}

\author{
B. M. Manasa*, Savitha Nagaraj and Harshad Devarbhavi
}

Department of Microbiology, Subbaiah Institute of Medical Sciences, Shivamogga, India

*Corresponding author

\begin{tabular}{l} 
K e y w o r d s \\
$\begin{array}{l}\text { Bacteriological profile, } \\
\text { Ascitic fluid, Chronic } \\
\text { liver disease, Antibiotic } \\
\text { susceptibility }\end{array}$ \\
\hline Article Info \\
$\begin{array}{l}\text { Accepted: } \\
\text { 04 November } 2019 \\
\text { Available Online: } \\
\text { 10 December } 2019\end{array}$ \\
\hline
\end{tabular}

\section{A B S T R A C T}

Spontaneous bacterial peritonitis (SBP) is a condition where there is development of monomicrobial infection of the ascitic fluid in the absence of any intra-abdominal source of infection and raise in the polymorphonuclear leukocyte cells (PMN) more than 250cells $/ \mathrm{mm}^{3}$. To describe the bacteriological profile and antibiotic susceptibility pattern of isolates in ascitic fluid from patients with SBP. Records of 500 patients with suspected diagnosis of SBP were analyzed for two years (January 2015- December 2016). All patients had undergone paracentesis after admission to the hospital. Ascitic fluid was cultured by automated blood culture (BacT/Alert) method. Antibiotic sensitivity testing was carried out by Kirby- Bauer disc diffusion method. Out of 500 cases of clinically suspected SBP, $483(96.6 \%)$ were males and $12(3.4 \%)$ were females. Study showed $25.6 \%(\mathrm{n}=128)$ of subjects had SBP. Classical SBP was seen in $28(21.8 \%)$, Bacterascites in $54(42.1 \%)$ and Culture negative neutrocytic ascites (CNNA) in 46 (35.93\%). Escherichia coli was isolated from 45(48.9\%) cases, Acinetobacter spp. from $8(8.88 \%)$, Pseudomonas spp. from 2 (2.22\%), Klebsiella spp. was isolated from 7 (7.77\%), Enterobacter species from 1(1.\%), Enterococcus spp. from 17 (18.47\%) and Staphylococcus aureus from 2(2.22\%). Resistance to cephalosporins and quinolones 45.5\% and 28.9\% were observed respectively. Escherichia coli and Enterococcus spp. were the most common organisms isolated. More than $50 \%$ of the Gram negative bacteria are resistant to the cephalosporins which are the most frequently used antibiotic.

\section{Introduction}

Spontaneous bacterial peritonitis (SBP) is the infection of the ascitic fluid that occurs in the absence of a visceral perforation and an intraabdominal inflammatory focus. (Caruntu and Benea, 2006) Criteria for the diagnosis of SBP are fulfilled if the polymorphonuclear neutrophil cells (PMN) count from the ascitic fluid is > 250 cells $/ \mathrm{mm}^{3}$ and culture yields growth of a single organism. Three variants of SBP have been described. They are Classical SBP (culture positive with raise in PMN cells), Bacterascites (culture positive but no raise in PMN), Culture negative neutrocytic ascitis (culture negative with raise in PMN). (Harrisons textbook of internal medicine)

In cirrhotic patients, common pathogens causing SBP are enteric in origin which 
account for 69\%. Escherichia coli followed by Klebsiella pneumoniae, Streptococcus pneumoniae and other Streptococcal species including Enterococci are the common organisms described.

Staphylococcus aureus is an unusual isolate in primary peritonitis accounting for 2- $4 \%$. (Harrisons textbook of internal medicine)

Automated systems have increased the yield by $90 \%$ in ascitic fluid culture. (Runyon et al., 1988) Complications like renal insufficiency, hypothermia, hyperbilirubenemia and hypoalbuminemia have been described if these patients (SBP) are not treated promptly. (Mandell, Douglas and Bennett's textbook of Principles and Practice of Infectious diseases)

The main objectives of this study includes to describe the bacteriological profile and the antibiotic susceptibility pattern of isolates obtained from ascitic fluid in patients, clinically diagnosed with spontaneous bacterial peritonitis.

\section{Materials and Methods}

The present study was a hospital based observational study, conducted on 500 clinically suspected cases of SBP from January 2015- December 2016, admitted in Gastroenterology and medical wards, in St. John's Medical College and Hospital, Bangalore.

All cases suspected to have known to have cirrhosis with ascites were included in this study. All patients with cirrhosis irrespective of aetiology of cirrhosis (alcohol, HCV, HBV, autoimmune, cryptogenic etc) were included in the study. Patients having secondary peritonitis due to appendicitis, gastrointestinal perforation, abdominal tuberculosis, septicemia, intestinal obstruction, trauma and malignancy and with history of antibiotic therapy were excluded from the study.

Patient's demographic details were collected and various presenting complaints such as abdominal distention, abdominal pain, pedal edema, fever, jaundice, decreased urine output, malena or loose stools were collected. Laboratory information system was used to collect data of patients and their detailed chart review was done.

The study was approved by the ethical committee of our institute (IEC Study Ref.No.13/2016)

\section{Methodology}

Ascitic fluid was collected with aseptic precautions, prior to administration of antibiotics and $10 \mathrm{ml}$ was directly inoculated into the blood culture blood in the wards. Ascitic fluid cultures were done by BacT/Alert Microbial Detection System and isolate identification done by standard phenotypic methods. Antimicrobial susceptibility testing was performed for all isolates by Kirby-Bauer disc diffusion method as recommended in the Clinical and Laboratory Standards Institute guidelines 2015. (CLSI, 2015)

The following antibiotics tested by disc diffusion: Ampicillin $(10 \mu \mathrm{g})$, Ciprofloxacin $(5 \mu \mathrm{g})$, Gentamicin $(10 \mu \mathrm{g})$, Amikacin $(30 \mu \mathrm{g})$, Netlimicin $(30 \mu \mathrm{g})$, Co-trimoxazole $(1.25 \mu \mathrm{g}$ Trimethoprim $/ 23.75 \mu \mathrm{g}$ Sulfamethoxazole), Meropenem $(10 \mu \mathrm{g})$, Piperacillin/Tazobactam $(100 / 10 \mu \mathrm{g})$ for Gram negative bacilli.

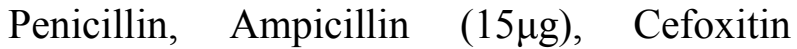
$(30 \mu \mathrm{g}), \quad$ Chloramphenicol $\quad(30 \mu \mathrm{g})$, Erythromycin $(15 \mu \mathrm{g})$, Vancomycin $(30 \mu \mathrm{g})$, Teicoplanin $(30 \mu \mathrm{g}))$, Ciprofloxacin, and Tetracycline $(30 \mu \mathrm{g})$ were used to determine the susceptibility patterns of the Gram positive cocci. 
Suspected patients with SBP underwent paracentesis aseptically before starting antibiotics

\section{$\downarrow$}

$10 \mathrm{ml}$ of ascitic fluid was collected in blood culture bottle and sent to laboratory (Runyon et al., 1988)

Ascitic fluid filled bottle was incubated in BacT Alert automated system

BactT Alert machine signals when there is growth of microorganism

Microorganism were identified by Gram staining, culture and biochemical reactions

Antibiotic susceptibility testing reported using by Kirby Bauer method (CLSI)

\section{Statistical analysis}

The results of the study were analysed using descriptive statistics. Continuous data was analysed using student $t$ test and categorical variables using chi square test. Fisher -exact test was done to find the association between the variables if the number of data was less than 5. $\mathrm{P}$ value $<0.05$ is considered as significant.

\section{Results and Discussion}

Out of the total 500 cases of clinically suspected SBP, 483(96.6\%) were males and $17(3.4 \%)$ were females. This high male to female ratio was probably due to the fact that most of the men 445(92.1\%) had history of alcohol intake. Maximum numbers of cases were in age group of $30-50$ years. The youngest case included in this study was 22 years and oldest case was 80 years. Mean age was $46.72 \pm 10.95$ years. (Table 1 )

The common presenting complaints of cases were abdominal distention followed by jaundice, fever, altered sensorium, oedema feet, pain abdomen and Upper gastrointestinal bleed. (Figure 1)

Of the 500 clinically suspected cases of SBP, the ascitic fluid demonstrated, polymorphonuclear cells $>250$ cells $/ \mathrm{mm}^{3}$ was seen among $73(14.6 \%)$ and cells $<250$ cells $/ \mathrm{mm}^{3}$ were seen in $427(85.4 \%)$ patients. Study showed $25.6 \%(\mathrm{n}=128)$ of subjects had SBP. 82/500 (16.4\%) yielded growth.

Among the culture positive patients, $28 / 82(21.8 \%)$ had raise in the polymorphonuclear cell count (Classical SBP) and 54/82(42.1\%) had $\mathrm{PMN}<250$ cells $/ \mathrm{mm}^{3}$ (Bacterascites). Of the 408 that where culture negative, 46/408(35.93\%) samples had raised PMN, labelled as culture negative neutrocytic ascites (CNNA).

Table 2 describes the variants of SBP, the common variant noticed was Bacterascites. Among the culture positive patients, $28 / 82(21.8 \%)$ had raise in the polymorphonuclear cell count (Classical SBP) and $54 / 92(42.1 \%)$ had $\mathrm{PMN}<250$ cells $/ \mathrm{mm}^{3}$ (Bacterascites).

The Neutrophil count $>250$ cells $/ \mathrm{mm}^{3}$ commonly seen among the age group of 30-50 years which was statistically significant $(\mathrm{p}<0.003)$. There was also statistical significance $(p<0.0001)$ in Neutrophil count $>$ 250 cells $/ \mathrm{mm}^{3}$ and Gram negative bacterial infection as a causative agent of SBP as shown in table 5 and table 6.

One isolate of Pseudomonas species was carbapenem resistant and colistin sensitive and other Pseudomonas isolate was sensitive to Cephalosporins.

One isolate of Enterobacter species was sensitive to Aminoglycosides and Cephalosporins. 
Table.1 Characteristics of SBP patients

\begin{tabular}{|l|c|}
\hline Parameters & \\
\hline No. Of patients(n) & 500 \\
\hline Age & $22-80$ years \\
\hline Mean age & $\begin{array}{c}46.72 \pm 10.95 \\
\text { years }\end{array}$ \\
\hline Male & $483(96.6 \%)$ \\
\hline Female & $17(3.4 \%)$ \\
\hline Alcohol induced Liver cirrhosis & $446(89.2 \%)$ \\
\hline HBV induced Liver cirrhosis & $35(7 \%)$ \\
\hline HCV induced Liver cirrhosis & $11(2.2 \%)$ \\
\hline Cryptogenic Liver cirrhosis & $8(1.6 \%)$ \\
\hline
\end{tabular}

Table.2 Variants of Spontaneous bacterial peritonitis: $n=128$

\begin{tabular}{|l|l|}
\hline Variants & Prevalence \\
\hline Classical SBP & $28(21.8 \%)$ \\
\hline Bacterascites & $54(42.1 \%)$ \\
\hline $\begin{array}{l}\text { Culture negative neutrocytic } \\
\text { ascitis }\end{array}$ & $46(35.93 \%)$ \\
\hline
\end{tabular}

Table.3 Organisms from samples which yielded culture positive: $\mathrm{n}=82$

\begin{tabular}{|l|c|c|}
\hline Bacteria & $\begin{array}{c}\text { No. of cases } \\
\mathbf{n = 8 2}\end{array}$ & Percentage \\
\hline Escherichia coli & 45 & $48.9 \%$ \\
\hline Enterococcus species & 17 & $18.47 \%$ \\
\hline Acinetobacter spp. & 8 & $8.88 \%$ \\
\hline Klebsiella spp. & 7 & $7.77 \%$ \\
\hline Pseudomonas species & 2 & $2.22 \%$ \\
\hline Staphylococcus aureus & 2 & $2.22 \%$ \\
\hline Enterobacter species & 1 & $1.11 \%$ \\
\hline
\end{tabular}

Table.4 Association between sex and immune status

\begin{tabular}{|l|c|c|c|}
\hline Sex & $\begin{array}{c}\text { Normal } \\
\text { immune } \\
\text { status }\end{array}$ & $\begin{array}{c}\text { HBs Ag } \\
\text { positive }\end{array}$ & $\begin{array}{c}\text { HCV } \\
\text { positive }\end{array}$ \\
\hline Males & $445(98.9 \%)$ & $26(74.3 \%)$ & $10(90.9 \%)$ \\
\hline Females & $5(1.1 \%)$ & $9(25.7)$ & $1(9.1 \%)$ \\
\hline
\end{tabular}

${ }^{\mathrm{b}} \mathrm{p}$ value calculated by Fishers exact test $\mathrm{p}$ value $<0.05$ is significant 
Table.5 Association between age in years and neutrophil count

\begin{tabular}{|l|l|l|l|l|}
\hline Age in years & $\begin{array}{l}\text { Neutrophil } \\
\text { count }<\mathbf{2 5 0} \\
\text { cells }\end{array}$ & $\begin{array}{l}\text { Neutrophil } \\
\text { count }>\mathbf{2 5 0} \\
\text { cells }\end{array}$ & $\begin{array}{l}\text { Test } \\
\text { value }\end{array}$ & P value \\
\hline < 30 years & $33(86.8 \%)$ & $5(13.2 \%)$ & & \\
\hline $\mathbf{3 0}$-50 years & $217(81.6 \%)$ & $49(18.4 \%)$ & $15.18^{\mathrm{a}}$ & $<0.001$ \\
\hline >50 years & $131(95.6 \%)$ & $6(4.4 \%)$ & & \\
\hline
\end{tabular}

${ }^{a} \mathrm{p}$ value calculated by Chi square test $\mathrm{p}$ value $<0.05$ is significant

Table.6 Association between age in years and common organism causing infection

\begin{tabular}{|l|l|l|l|l|}
\hline Age in years & $\begin{array}{l}\text { Gram negative } \\
\text { bacteria }\end{array}$ & $\begin{array}{l}\text { Gram positive } \\
\text { bacteria }\end{array}$ & Test value & P value \\
\hline < 30 years & $2(40 \%)$ & $3(60 \%)$ & & \\
\hline $\mathbf{3 0}$-50 years & $32(86.4 \%)$ & $7(17.94 \%)$ & $18.78^{\mathrm{b}}$ & 0.001 \\
\hline$>\mathbf{5 0}$ years & $19(51.35 \%)$ & $18(48.6 \%)$ & & \\
\hline
\end{tabular}

${ }^{\mathrm{b}} \mathrm{p}$ value calculated by Fishers exact test $\mathrm{p}$ value $<0.05$ is significant

Table.7 Antibiotic susceptibility pattern of Gram negative bacteria

\begin{tabular}{|l|l|l|l|}
\hline Antibiotics & $\begin{array}{l}\text { E.coli } \\
(\mathbf{n = 4 5})\end{array}$ & $\begin{array}{l}\text { Acinetobacter } \\
\text { spp.(n=8) }\end{array}$ & $\begin{array}{l}\text { Klebsiella } \\
\text { spp.(n=7) }\end{array}$ \\
\hline $\begin{array}{l}\text { Aminoglycosides (gentamicin, } \\
\text { amikacin, netilmycin) }\end{array}$ & $33(73.33 \%)$ & $34 \%$ & $4(57.1 \%)$ \\
\hline $\begin{array}{l}\text { Cephalosporins (cefotaxime, } \\
\text { ceftazidime) }\end{array}$ & $25(55.5 \%)$ & $0 \%$ & $4(57.1 \%)$ \\
\hline Fluoroquinolones (ciprofloxacin) & $32(71.1 \%)$ & $33.8 \%$ & $4(57.1 \%)$ \\
\hline Carbapenemes (Meropenem)* & $41(91.1 \%)$ & $57.1 \%$ & $50 \%$ \\
\hline $\begin{array}{l}\text { Piptaz (aminopenicillin + Beta } \\
\text { lactamase inhibitor) }\end{array}$ & $35(77.7 \%)$ & $0 \%$ & $50 \%$ \\
\hline
\end{tabular}

*Isolates that were resistant to Meropenem, were sensitive to Colistin and Tigecyclin.

Table.8 Distribution of variants of SBP documented in present as compared to other studies

\begin{tabular}{|c|c|c|c|c|c|}
\hline Variant SBP & $\begin{array}{l}\text { Present } \\
\text { study } \\
\mathbf{N}=500\end{array}$ & $\begin{array}{l}\underset{\text { Jeevan }}{(8)} \\
\text { al., } \\
\mathbf{N}=\mathbf{3 0 0}\end{array}$ & $\begin{array}{l}\text { Kavita } \\
\text { al., }(10) \\
\mathrm{N}=122\end{array}$ & $\begin{array}{l}\text { Purohit et } \\
\text { al., }{ }^{(7)} \\
\mathrm{N}=217\end{array}$ & $\begin{array}{l}\underset{\text { Vandana et }}{\text { al., }} \\
\mathrm{N}=600\end{array}$ \\
\hline Study period & $\begin{array}{l}\text { Jan2015-Dec } \\
2016\end{array}$ & $\begin{array}{l}\text { Jan2014-dec } \\
2014\end{array}$ & $\begin{array}{l}\text { March2012- } \\
\text { May } 2013\end{array}$ & $\begin{array}{l}\text { Dec2011-Nov } \\
2012\end{array}$ & $\begin{array}{l}\text { Jan2007-Dec } \\
2011\end{array}$ \\
\hline CNNA & $35.93 \%$ & $47 \%$ & $80 \%$ & $56.4 \%$ & $57.1 \%$ \\
\hline Classical SBP & $21.8 \%$ & $51 \%$ & $12 \%$ & $43.6 \%$ & $35.8 \%$ \\
\hline Bacterascites & $42.1 \%$ & $2 \%$ & $8 \%$ & $\begin{array}{l}\text { Did not } \\
\text { comment }\end{array}$ & $7 \%$ \\
\hline
\end{tabular}


Table.9 Comparison of distribution of the isolates between our study and other studies

\begin{tabular}{|c|c|c|c|c|c|c|}
\hline Isolate & $\begin{array}{l}\text { Present study } \\
\%\end{array}$ & $\begin{array}{l}\text { Jeevan et al., }{ }^{(8)} \\
\%\end{array}$ & $\begin{array}{l}\text { Reuken } \text { et al., } \\
\%\end{array}$ & $\begin{array}{l}\text { Purohit et al., }{ }^{(7)} \\
\%\end{array}$ & $\begin{array}{l}\text { Vandana et al., } \\
\%\end{array}$ & $\begin{array}{l}\text { Tsung } \\
\text { al., }{ }^{(11)}\end{array} \quad$ et \\
\hline Escherichia coli & $48.9 \%(n=45)$ & $37.5 \%$ & $64.5 \%$ & $54.9 \%(n=17)$ & $50 \%(\mathrm{n}=15)$ & $25 \%$ \\
\hline Klebsiella spp. & $7.77 \%(\mathrm{n}=7)$ & $16.6 \%$ & $10.41 \%$ & $16.2 \%(\mathrm{n}=5)$ & $16.66 \%(\mathrm{n}=5)$ & $19.1 \%$ \\
\hline Acinetobacter spp. & $8.88 \%(\mathrm{n}=8)$ & - & $2.08 \%$ & - & $3.33 \%(\mathrm{n}=1)$ & $2.1 \%$ \\
\hline Pseudomonas spp. & $2.22 \%(n=2)$ & - & $6.25 \%$ & $9.6 \%(n=3)$ & $6.66 \%(n=2)$ & $4.3 \%$ \\
\hline Enterobacter spp. & $1.11 \%(\mathrm{n}=1)$ & - & $4.16 \%$ & - & $6.66 \%(n=2)$ & $4.3 \%$ \\
\hline Enterococcus spp. & $18.47 \%^{*}(\mathrm{n}=17)$ & $16.66 \%$ & $39.5 \%$ & - & - & $12.8 \%$ \\
\hline $\begin{array}{l}\text { Staphylococcus } \\
\text { aureus }\end{array}$ & $2.22 \%^{* *}(\mathrm{n}=2)$ & - & $16.66 \%$ & $19.3 \%(n=6)$ & - & $6.4 \%$ \\
\hline
\end{tabular}

**All the Staphylococcus aureus isolates in our study were sensitive to Methicillin.

*All the Enterococcus species except for one isolate were sensitive to Glycopeptides

Table.10 Sensitivity pattern of the Gram negative bacilli from our study and related studies

\begin{tabular}{|c|c|c|c|}
\hline Antibiotics & $\begin{array}{c}\text { Present study } \\
\%\end{array}$ & $\begin{array}{l}\text { Jeevan et } \\
\text { al. }^{(8)^{*}}\end{array}$ & Vandana et al., ${ }^{(6) *}$ \\
\hline $\begin{array}{l}\text { Third generation } \\
\text { Cephalosporins }\end{array}$ & $55.5 \%$ & $50 \%$ & $50 \%$ \\
\hline Quinolones & $71.1 \%$ & $53.3 \%$ & $53.3 \%$ \\
\hline Aminoglycosides & $73.3 \%$ & - & - \\
\hline $\begin{array}{l}\text { Pipercillin- } \\
\text { Tazobactam }\end{array}$ & $77.7 \%$ & $70 \%$ & $70 \%$ \\
\hline Meropenem & $91.1 \%$ & - & $96.6 \%$ \\
\hline
\end{tabular}

*Studies have reported as overall sensitivity of the isolates.

Fig.1 Describing various clinical features of the participants in the study population

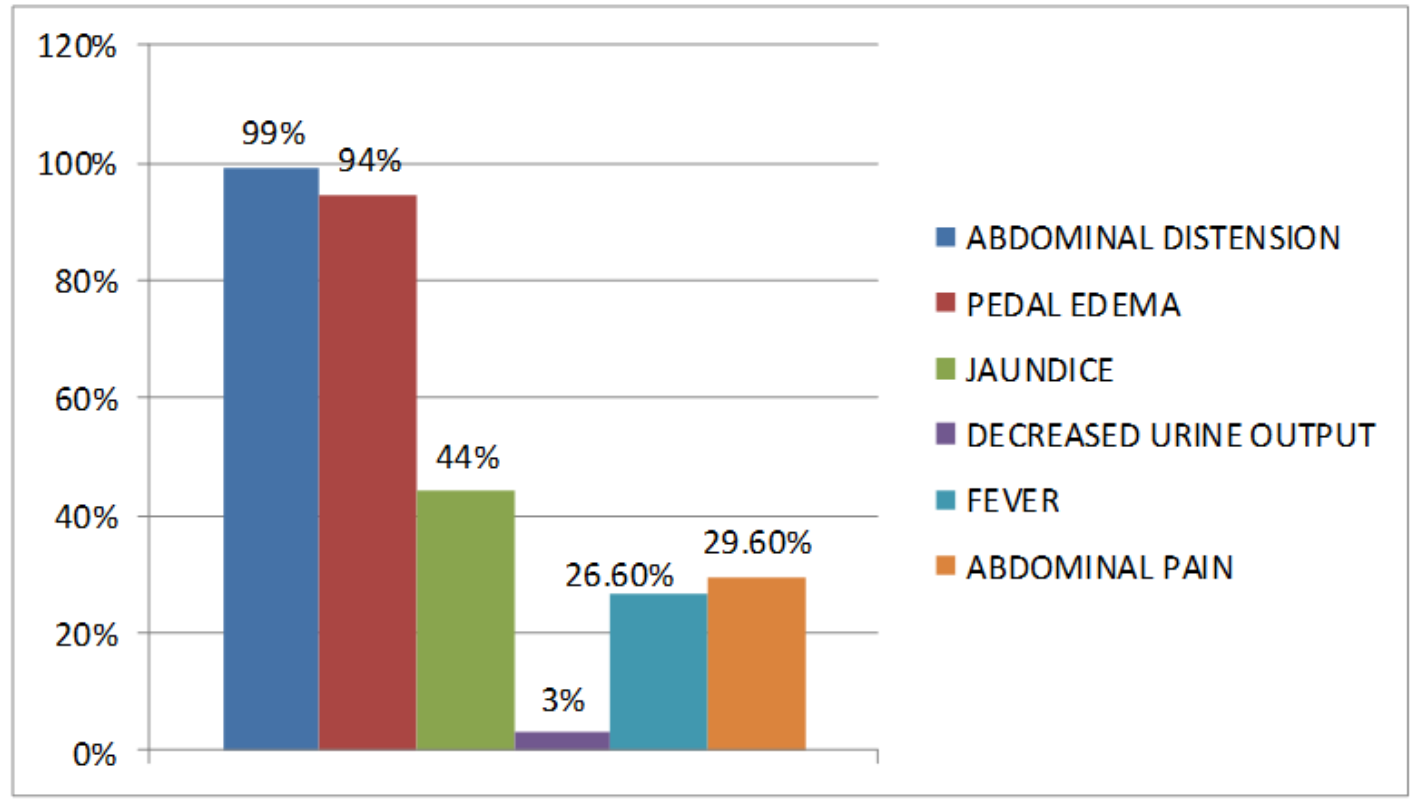


Antibiotic sensitivity of Gram positive bacteria was out of 17 isolates of Enterococcus species, $11(69.2 \%)$ were sensitive to penicillin, $11(69.2 \%)$ were sensitive to aminoglycosides, $16(94.11 \%)$ were sensitive to ciprofloxacin and 16 (94.11\%) were sensitive to glycopeptides. One strain of Enterococcus spp. was resistant to Vancomycin.

Two strains of Staphylococcus aureus were sensitive to Penicillin, Methicillin, Erythromycin, Aminoglycosides, Fluoroquinolones.

Our study comprised subjects between 22-80 years $(46.5 \pm 10.8$ years $), 483(96.6 \%)$ were males and 17 (3.4\%) were females.

Alcohol intake was the commonest reason for liver cirrhosis and SBP, accounting to $89.2 \%$ which is similar to the study conducted by Jeevan et al., [2015] followed by Hepatitis B induced liver cirrhosis (7\%), Hepatitis C induced liver diseases (2.2\%) and Cryptogenic causes of liver cirrhosis, contributing to $1.6 \%$.

The clinical manifestations of SBP have a varied presentation. Most patients of SBP in our study had symptoms and or signs clearly suggestive of peritoneal infection, especially pain abdomen, fever and altered gastrointestinal motility, similar presentation has been reported by various other studies.

Mihas et al., reported varied manifestations ranging from fever to gastrointestinal bleeding and hepatic encephalopathy (Mihas et al., 1992).

Other studies report that patients may present with development of hepatic encephalopathy or renal failure which may be the predominant or only feature at the time of presentation to the hospital. (Payal H. Purohit et al., 2015)
The clinical presentations found in this study were fever (26.6\%), abdominal distention (99\%), pedal edema (94\%), encephalopathy $(38 \%)$ jaundice $(44 \%)$ and decreased urine output (3\%). Subjects commonly presented with abdominal distension in combination with pedal edema and jaundice.

All cirrhotic patients with ascites are prone to develop SBP. The prevalence of SBP in hospitalized patients with cirrhosis and ascites is between 10\% and 30\%. (Bhat et al., 2013) Prevalence of SBP and its variants in our study is $27.8 \%$ that is similar to the findings by Puri et al., [1996]. SBP was commonly seen among males in the age group of 30-50 years that is comparable to other studies [Payal H. Purohit et al., 2015].

Common variant of SBP was Bacterascites $42.1 \%$ followed by CNNA- $35.93 \%$ and classical SBP- $21.8 \%$.

Neutrophil count > 250 cells $/ \mathrm{mm}^{3}$ was commonly seen in age group of 30-50 years which was statistically significant. Gram negative bacterial infection and neutrophilic counts $>250$ cells $/ \mathrm{mm}^{3}$ were commonly seen among age group of 30-50 years which was statistically significant.

SBP was detected in $27.8 \%$ of the patients in our study group. The most common causative organism of SBP was enteric gram negative bacilli (Escherichia coli) followed by Entercoccus species. Resistance to cephalosporins and quinolones was $45.5 \%$ and $28.9 \%$ and alcoholic liver disease was the commonest etiology of liver cirrhosis.

\section{References}

Bhat, G., Vandana.KE, Bhatia S, Suvarna D, Pai, CG. Spontaneous ascitic fluid infection in liver cirrhosis: bacteriological profile and response to 
antibiotic therapy. Indian J Gastroenterology. 2013; 32(5): 297-301

Caruntu F.A., and Benea. L, Spontaneous bacterial peritonitis: Pathogenesis, diagnosis and treatment. J Gastro Liver Disease March 2006; 15: 51-56.

Clinical and Laboratory Standards Institute guidelines (CLSI) (Clinical and laboratory standards Institute M100S25, 2015)

Harrisons textbook of internal medicine $18^{\text {th }}$ edition volume 1 (127): 1077-1079

Jeevan, H.R., Nandeesh, H.P., Deepak Suvarna, Vidya, G.S. Spontaneous ascitic fluid infection in liver cirrhosis: Bacteriological profile among patients admitted in a tertiary care hospital, Mysore. International Journal of Current Research. 2015; 7(6): 1697316975

Mandell, Douglas and Bennett's textbook of Principles and Practice of Infectious diseases, $6^{\text {th }}$ Edition volume one (68): 929-931

Mihas AA, Toussaint J, Hsu HS, Dotherow P, Achord JL. Spontaneous bacterial peritonitis in cirrhosis: clinical and laboratory features, survival and prognostic indicators. Hepatogastroenterology 1992; 39(6): $520-2$.

Paul. K, Kaur. J, Lal Kazaal. H. Incidence, Predictive Factors and Clinical Outcome of Spontaneous Bacterial Peritonitis, J Clin Diag Res. 2015 Jul, Vol-9(7): OC09-OC12
Payal H. Purohit, Malek. S, J Desai. K, Sadadia P.H. M. A study of bacteriological profile of ascitic fluid in suspected clinical cases of spontaneous bacterial peritonitis at a tertiary care hospital in India. International Journal of Medical Science and Public Health. 2015; 4(4): 496-501.

Puri AS, Puri J, Ghoshal UC, Sharma BC, Saraswat VA, Ayyagari A, et al., Frequency, microbial spectrum and outcome of spontaneous bacterial peritonitis. Indian J Gastroenterol 1996; 15(3): $86-8$

Reuken, P.A., M. W. Pletz, M. Baier, W. Pfister, A. Stallmach \& T. Bruns. Emergence of spontaneous bacterial peritonitis due to enterococci - risk factors and outcome in a 12yearretrospective study. Alimentary Pharmacology and Therapeutics. 2012; 35: 1199-1208

Runyon BA, Canawati HN, Akriviadis EA. Optimisation of ascitic fluid culture technique. Gastroenterology 1988; 95:1351-5.

Runyon BA. Monomicrobial non-neutrocytic bacterascites: A variant of spontaneous bacterial peritonitis. Hepatology. 1990; 12: $710-15$.

Tsung. P, Ryu. S.H, Cha. H, Cho. H.W, Kim. J.N, Kim. Y.S, and Moon. J.S. Predictive factors that influence the survival rates in liver cirrhosis patients with spontaneous bacterial peritonitis. Clinical and Molecular Hepatology 2013; 19: 131-139

\section{How to cite this article:}

Manasa B. M., Savitha Nagaraj and Harshad Devarbhavi. 2019. Bacteriological Profile and Antibiotic Susceptibility Pattern of Isolates from Ascitic Fluid among Patients Diagnosed With Chronic Liver Disease in a Tertiary Care Hospital: An Observational Study. Int.J.Curr.Microbiol.App.Sci. 8(12): 3012-3019. doi: https://doi.org/10.20546/ijcmas.2019.812.350 